\title{
Android Technology-Based Educative Games for Children with Intellectual Disability: A Case Study at Yayasan Peduli Kasih Anak Berkebutuhan Khusus
}

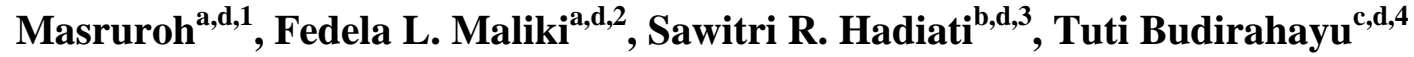 \\ ${ }^{a}$ Postgraduate Program, Universitas Negeri Surabaya, Ketintang, Surabaya 60231, Indonesia \\ ${ }^{\mathrm{b}}$ Department of Public Health, Faculty of Medicine, Universitas Airlangga, Moestopo, Surabaya 60131, Indonesia \\ ${ }^{\mathrm{c}}$ Department of Sociology, Faculty of Social and Politics, Universitas Airlangga, Dharmawangsa, Surabaya 60286, Indonesia \\ ${ }^{\mathrm{d}}$ Pusat Kajian dan Pelayanan Peduli Anak Berkebutuhan Khusus, Ngagel Kebonsari, Surabaya, 60245, Indonesia \\ ${ }^{1}$ ismi_masruroh@yahoo.com, ${ }^{2}$ nenk.felema88@gmail.com, ${ }^{3}$ sretnoh@yahoo.com, ${ }^{4}$ tutibudirahayu@yahoo.com
}

\begin{abstract}
The mental age of children with Intellectual Disability $(I D)$ is lower than their chronological age. They have limited ability to memorize something. Therefore, it is difficult for them to learn how to read, particularly in recognizing letters and spelling words. The use of appropriate technology and importance of the closest people around them may optimize their intellectual development. One of the technology can be used in this case is educative games applications from Play store. This kind of game applications can attract them and provide assistance in learning. The objective of this study is to describe the effectiveness of educative games "Marbel Huruf and Belajar Membaca" to assist children with ID in reading in the first stage. This study is limited only in reading due to a complexity of this ability. The subject of this study was one of Yayasan Kasih Anak Berkebutuhan Khusus' (YPKABK) female students with Down syndrome, whose age is 15 years old, but her mental age is still in 5 and she cannot read yet. Data of student's reading skill were obtained through observations. Observations were done during a month period. It was conducted between the middle of May and the middle of June. It was done repeatedly for giving her a chance to repeat what she has learned. The result showed subject's enthusiasm through learning activities, high motivation, and an increase in ability even she has not reached an optimum stage yet. Family's interaction and participation were also necessary. This finding suggests that the teaching and learning process at YPKABK be embedded with technology (ICT).

Index Term - Educative Games, Intellectual Disability, Reading Skill.
\end{abstract}

\section{Introduction}

We live in a diverse society and have to realize that we live among people with intellectual disability, particularly, people with Down Syndrome (DS). During the last 17 years, the number of births with DS increase rapidly accounted for 1:700 for every birth [1]. Today, the exact number of people with DS is unknown. The estimated number of people with DS in the world reaches 8,000,000 cases, 300,000 of them live in Indonesia (3.75\%) [1]. In Surabaya, this number is estimated to 924 cases [1]. Most of them are dependent to their closest people due to their different abilities. Most of them never experience school life; therefore, they cannot acquire basic skills such as reading.

In fact, reading is a basic important skill needed in our daily life, even tough, today we can find our way with oral GPS instructions, and use voice-activated software to write our thoughts. Assisted technologies, including computer software that reads text, speech recognition software, talking calculators and advanced spell check software are common [2]. Reference [3] listed many valid reasons that reading is important; these include getting a license and driving a car, going on a trip, ordering food at a restaurant, buying something on time, getting a job, getting new information from newspaper and magazines, going to a doctor, and reading instructions on medicine bottles. Adults who cannot read have trouble living independently and successfully.

One of Non-Governmental Organizations (NGOs) which cares for children with special needs, including children with DS is Yayasan Peduli Kasih Anak Berkebutuhan Khusus (YPKABK). YPKABK pays more attention to children with special needs, particularly those who come from poor families. This NGO was founded on April 4th, 2012 and located in Ngagel Kebonsari Street I/10 Surabaya. Firstly, this NGO staff looked for children with special needs by surveying from door to door and getting a report from the society. YPKABK helps children with special needs by giving them financial and moral support, including their parents. Besides, YPKABK also gives opportunities to those children to get school life experiences by providing assistances to join in Inclusion Elementary school and holding a class at YPKABK itself. Learning activity at YPKABK is held three days per week.

Almost all of the children with special needs at YPKABK have difficulty when they learn to read. Only 1 out of 29 children can read, and 3 of them have the ability to recognize letters. It is difficult for them to learn how to read, particularly in recognizing letters and spelling words. What is more, they have limited ability to memorize something.

The use of appropriate assisted technology, particularly, game applications, and the role of the closest people around them may optimize their intellectual development. One of the technologies that can be used in this case is educative game applications from Play Store. They are "Marbel Huruf and Belajar Membaca". These game applications can attract them and provide assistances in learning to read. Therefore, the objective of this study is to describe the effectiveness of educative games "Marbel Huruf and Belajar Membaca" to assist children with ID in reading in the first stage.

\section{Review of Related Literature}

\section{A. Down Syndrome (DS)}

Down syndrome (DS) is a congenital condition which randomly affects about 1 in every 700 babies born 
throughout the world, male and female. DS is caused by an extra copy of chromosome number 21 in each of the body's cells [4]. Down syndrome is usually caused by an error in cell division called non-disjunction. However, two other types of chromosomal abnormalities, mosaicism and translocation, are also implicated in Down syndrome, although a much lesser extent. This additional genetic material alters the course of development and causes the characteristics associated with the syndrome [5]. Reference [4] noted that there will be a degree of learning difficulty and certain common facial features. No other characteristic is present in every individual.

DS is recognizable at birth. As cited from reference [4] there are several physical characteristics of children with DS. The child usually has a rounded face with a flattish profile. The child's head is often smaller than average, caused by underdevelopment of the facial bones. The back of the child's head may be slightly flattened and the neck may appear short. A child with DS may have a small mouth, with a flattish roof. This gives the tongue less space, making it more likely to protrude initially. This tendency is increased by weakness of the tongue and jaw muscles. The eyes of nearly all people with DS slant slightly upwards. Arms and legs are often short in relation to the body, and hands may be broad with short fingers. The little finger may have one joint instead of two, curving in towards the other fingers. The palm often has only one crease across it. Feet tend to be broad with short toes, and there is a space between the big toe and the second.

Furthermore, children with DS tend to have Congenital Heart Disease (CHD). About 1 in 3 children born with DS have a CHD [4]. CHD is a heart defect which is present at birth. Therefore, it is called congenital heart disease (CHD). In addition, there are several health problems commonly experienced by children with DS, such as upper respiratory tract infections, constipation, poor muscle tone, and other diseases that affect their ears and eye [4].

On the other hand, children with DS can be categorized as children with intellectual disability (ID), even though there are other circumstances categorized as ID such as mental retardation (MR), Attention Deficit Hyperactivity Disorder (ADHD), autism, epilepsy, dyslexia, etc. [6]. The mental age of children with DS is usually lower than their chronological age. They are likely to have learning difficulties due to their limited ability to memorize something and to stay focused on what they learn. Children with DS often have particular difficulties with their understanding and expression of language [4].

Regarding all of those characteristics, children with DS are easily distinguished from others. They are different in their ability and their needs. As stated by reference [4], children with DS develop and learn throughout life, increase skills in the same way as other children, but at a slower pace. Therefore, a special treatment is necessary to teach them, for they have different abilities. They need more attention and more time to learn something. What is more, they are similar as other children who need to learn basic skills to be able to live independently in the future.

\section{B. Reading Skills in Down Syndrome}

Reading is an important basic skill to live independently. Moreover, people with intellectual disability, particularly people with DS need to live independently. Furthermore, reading is an essential component of success in most academic subjects, and functional literacy is needed for students with intellectual disabilities to achieve independence [7]. A lack of reading skill limits one's quality of life [8].

Reading and literacy skills are the keys to access knowledge, gain independence, and make choices [9]. A slow development of reading skills may affect more than just one academic subject, and also delay language acquisition, general knowledge, vocabulary, as well as social acceptance [2].

That is the reason why people who cannot read, such as children with DS are likely to be discriminated in their society. Most of the children with DS tend to be passive due to their limited communication skill that in turn affects their social acceptance.

The components of reading named by the National Reading Panel (NRP) [9] included: phonemic awareness, phonics instruction, fluency, vocabulary instruction, and comprehension. Phonetic awareness is an ability to hear, identify, and manipulate the individual sounds (phonemes) in spoken words. Phonics is an ability to understand between letters, written language, and sounds of spoken language. Fluency is an ability to read a text accurately, quickly, and with proper expression. Vocabulary is the ability to use words to communicate effectively in speaking and listening (oral vocabulary) or to recognize or use in print (reading vocabulary).

Reference [9] stated that there are three general stages of reading development. They are pre-reading stage in which students develop language skills and awareness, learning to read stage in which students focus on build skills to read words, and reading to learn stage in which students are expanding their reading vocabulary and comprehension skills.

A review of research focusing on students with intellectual disabilities noted that although reading requires mastery of several related skills, most reading instruction with intellectually disabled students focused on components of reading [10].

The mental age of children with ID is lower than their chronological age. They have limited ability to memorize. However, within the first stage of reading development, they begin to realize that written letters represent spoken words, and acquire some initial familiarity with letters. Students often learn to recite letters during this phase. Therefore, it is difficult for them to learn how to read, particularly in recognizing letters and spelling words.

\section{Games for Learning Disability}

Assisted technology, including game applications can be used to help children with learning disability. Even though learning disabilities cannot be cured or fixed, but with the help of certain tools and techniques, a child with a learning disability can solve his or her difficulties in reading, writing, spelling, math, organization or memory [11]. Assisted technology can motivate students with ID to focus and stay in their learning. In a review of 128 studies of reading interventions with one or more students with moderate to severe cognitive disabilities, noted that most 
interventions were found to focus on sight words, with about $33 \%$ using picture identification tasks [12].

Commonly, game applications contain colorful pictures and attractive sound. Picture fading and letter-tracing techniques show a greater delayed word response, so words were remembered longer [13]. It is necessary to keep students with intellectual disabilities focused. The students with intellectual disabilities took twice as long to complete lessons as other struggling readers. Furthermore, intensive number of repetitions and practice on critical literacy skills are needed to produce meaningful achievement in reading [10].

Game applications, assisting children to learn how to read available in Play Store such as "Marbel Huruf and Belajar Membaca" can be used to help children with ID to learn reading. It contains colorful pictures and playful sounds that attract children with ID to stay focused on learning.

Besides the assistance of games application, closest people play an important role. Children with ID may feel more comfortable if they are assisted by family members or the closest people. Moreover, their learning process should be conducted continuously. If the process stops, then they will no longer memorize what they have learned. It needs to start from the beginning again. Thus, the use of appropriate technology and importance of the closest people around them may optimize their intellectual development.

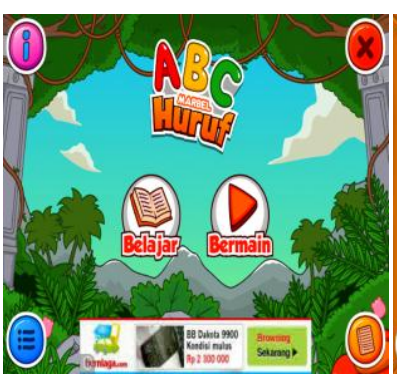

(a)

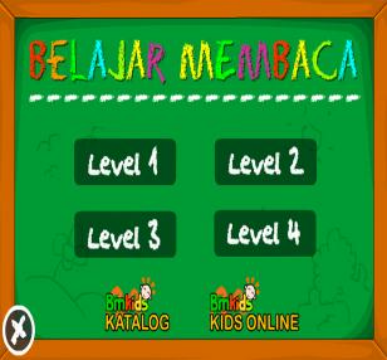

(b)
Fig. 1 The appearance of (a) "Marbel Huruf" and (b) "Belajar Membaca"

\section{Research Method}

This study is a descriptive study. The subject of this study was one of YPKABK female students with Down syndrome whose age is 15 years old. Her mental age is still in 5 and she cannot read yet. The subject was screened for the following entry level skills prior to the study: (a) her visual ability to make selections on the mobile phone screen; and (b) her physical ability to recite after she listens to a word based on the mobile phone screen and audio.

The main data were collected by observing and interviewing the subject, subject's family, and the closest people around her. The interviewers in this study were the researchers themselves. Consequently, the researchers acted as the main instruments. Beside researchers, there was an instrument utilized to support the main instrument in order to obtain the intended information. The instrument was educative game applications "Marbel Huruf" and "Belajar Membaca". These educative game applications are available in Play store. "Marbel Huruf" is an educative game application to help children recognized letters A-Z which is suitable for children 3-5 years-old. This application comes with a sound of each letter so that children can follow easily, while "Belajar Membaca" is an educative game application to enhance reading skill. There are 4 levels to accommodate the capability of the children: 1) words in 3 letters, 2) 4 letters, 3) 5 letters and 4) two words with 4 letters each. In this study, the subject was treated in the level of 3 letters word (Level 1).

The study was limited only in reading due to the complexity of this skill. The data of Subject's reading skill were obtained through observations while data on the subject's background were obtained through interviews with subject's family and instructor in YPKABK. Observations were done during a month period. It was conducted between the middle of May and the middle of June. It was done repeatedly for giving her chances to repeat what she had learned.

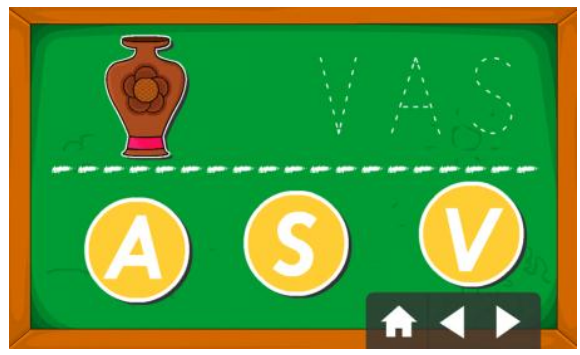

Fig. 3 Read simple word

\section{Results and Discussion}

\section{A. Results}

Based on the interview with the subject's mother, the subject grew up without her father's care and love as he passed away when she was under 5 years of age. Her mother works as a part-time domestic worker. She has 3 siblings and she is the youngest. Her mother knew that she had Down syndrome when she was 4 months. When she was a child, her mother allowed her to play and socialize with normal children, but when she is a grown up and has got her first period, she was not allowed to socialize with other people around her anymore. Fortunately, she was allowed to socialize with her friends at her school and YPKABK.

The subject is the first student who joined YPKABK when this NGO was founded. She was 13 years old at that time, but she never had gotten any experiences at school, whether PAUD (Childhood education) nor kindergarten. Based on her Psycho test result, it showed that her mental age is still in 5 which is way below her chronological age. She should be in PAUD (Childhood education) with that mental age, but her mother wants to send her to Elementary school. YPKABK is aware of her mother's dream and help her to join the Inclusion Elementary School. Today she is studying at Inclusion school in SDN Ngagel 3 Surabaya.

The subject is a diligent student. She has great motivation to learn. It is showed by her presence in the activity of learning at YPKABK. This may be one special characteristic of children with DS, if they have a particular interest, they are very eager in doing an activity. Furthermore, she is a communicative student at YPKABK. It is showed by her ability to respond the researchers' questions and instruction. 
During this study, researchers found subject's enthusiasm through a learning activity, high motivation, and an increase in reading skill even though she has not reached an optimum stage yet. The first time, subject saw "Marbel Huruf" she looked interested and followed the researcher's instruction well. She tried to focus on what she had learned, and maintained her concentration which was a good progress. During observation, the subject showed high motivation during the learning activity. She enjoyed the lesson from the game application. She tried to memorize the sound of a letter and the letter itself.

The subject also showed an increase in reading skill even though she has not reached an optimum stage yet. It was shown by her ability to hear and imitate the sound pronounced by the game application "Marbel Huruf". On the next page on this game where there was a matching letters game, the subject tried to match the letters and she finished the game successfully although she failed sometimes. However, on the first level of the next game application "Belajar Membaca" where there was a simple word contains three letters, the subject failed to read the word. She just showed the ability to hear and imitate the sound of letters pronounced by the game application. Thus, it showed that she just reached the first stage of reading development that is a pre - reading stage in which students develop language skills and awareness. The subject acquired two out of five components of reading named by NRP: they are phonetic awareness and phonics. She was able to hear, identify, and manipulate individual sounds in spoken words. In addition, she tried to understand and correlate between the individual sound of the letter and its written form.

\section{B. Discussion}

The researchers pointed out that the subject has not reached an optimum stage yet. She just reached the first stage of reading development that is a pre - reading stage in which students develop language skills and awareness. Within the first stage of reading development, they begin to be aware that the written form represents spoken words, and they begin to realize some initial familiarity with letters. Students often learn to recite the letters during this phase. Therefore, it is difficult for them to learn how to read, particularly in recognizing letters and spelling words due to their limited ability to memorize. Moreover, students with ID need more time and continuous practice to learn something. As stated by [10], students with ID took twice as long to complete the lessons as other struggling readers. Furthermore, intensive number of repetitions and practices of critical literacy skills are needed to produce meaningful achievement in reading. Overall, even though the subject only reached the first stage of reading development, the progress in reading skills is showed by the subject was a good achievement for children with DS.

\section{Conclusion}

The result showed educative game applications "Marbel Huruf" and "Belajar Membaca" helped attract the subject's enthusiasm through a learning activity, motivation, and increase in reading skill even though the games were unable to help the subject to reach an optimum stage yet. However, this educative game application can be used as an alternative learning media to motivate and attract children with DS.

\section{Recommendation for Further Research}

This study suggests YPKABK be embedded ICT (Information and Communication Technology) in the learning and for the further research it is necessary to apply this educative game application in a wider screen such as tablets or computers to be used easily by students in order to help them in reading. Any technology breakthrough in teaching students with DS that help them reach an optimum stage in reading may be worthwhile researched.

\section{Acknowledgements}

We would like to grateful to the staff of YPKABK for her assistance for this study. We would also like to thank to Subject's family for their cooperation in this study. Last but not least, we would like to thank our friends at Postgraduate Program of Universitas Negeri Surabaya and Universitas Airlangga for their moral support during our study.

\section{References}

[1] A. Mulia and K. Eunike. "Fasilitas terapi anak Down syndrome di Surabaya," Jurnal eDimensi Arsitektur, no. 1, pp. 1-6, 2012.

[2] R. Mahlburg, Reading and Students with Intellectual Dissabilities: Using the Readers Workshop Model to Provide Balanced Literacy Instruction, Lynchburg: Lynchburg College, 2013.

[3] C. Mackay, Why do I Need to Learn to Read, Retrieved June $25^{\text {th }}$ 2014 from http://ezinearticles.com/?Why-Do-I-Need-to-Learn-toRead\&id=897851, 2007.

[4] Scottish Down Syndrome Association, What is Down's Syndrome? Information for Parents, Carriers, Professional, and Students, Scottish Down Syndrome Association.

[5] National Down Syndrome Society, About Down Syndrome, Retrieved May $24^{\text {th }} 2014$ from http://www.ndss.org.

[6] Kenya Society for the Mentally Handicapped, Types of Intellectual Disabilities, Retrieved $1^{\text {st }}$ July 2014 from http://www.ksmh.org/component/content/article/88/240-types-ofintellectual-disabilities.

[7] E. A. Polloway, J. R. Patton, L. Serna, and J. W. Bailey, Strategies for teaching learners with special needs $\left(10^{\text {th }}\right.$ Ed.), Columbus, $\mathrm{OH}$ : Pearson, 2013.

[8] S. Bradford, M. E. Shippen, P. Alberto, D. E. Houschins, and M. Flores, "Using systematic instruction to teach decoding skills to middle school students with moderate intellectual disabilities, Education and Training in Developmental Disabilities, " vol. 41, no. 4, pp. 333-343, 2006.

[9] D. Houston, and J. Torgeson, Teaching students with moderate disabilities to read: Insights from research, Bureau of Instructional Support and Community Services, Florida Department of Education, Retrieved June $25^{\text {th }} \quad 2014$ from https://www.ocps.net/cs/ese/programs/cognitive/Documents/Teachin g\%20Students\%20with\%20Moderate\%20Disabilities\%20to\%20Rea d.pdf, 2004.

[10] J. H. Allor, P. G. Mathes, J. K. Roberts, F. G. Jones, and T. M. Champlin, "Teaching students with moderate intellectual disabilities to read: An experimental examination of a comprehensive reading intervention, " Education and Training in Autism and Developmental Disabilities Journal, vol. 45, no. 1, pp. 3-22, 2010.

[11] National Center for Learning Disabilities, An Overview of Assistive Technology, Retrieved June $25^{\text {th }} 2014$ from http://www.ncld.org/students-disabilities/assistive-technologyeducation/overview-assistive-technology, 2013.

[12] D.M. Browder, S.Y. Wakeman, L. Ahlbrim-Delzell, and B. Algozzine, "Research on reading instruction for individuals with significant cognitive disabilities, " Exceptional Children, vol. 72, pp. 392-408, 2006.

[13] S. I. Barudin and J. J. Hourcade, "Relative effectiveness of three methods of reading instruction in developing specific recall and transfer skills in learners with moderate and severe mental retardation," Education and Training in Mental Retardation, vol. 25, pp. 286-291, 1990. 